\title{
DNA polymorphism at the omp-31 locus of Brucella spp.: evidence for a large deletion in Brucella abortus, and other species-specific markers
}

\author{
Nieves Vizcaíno, † Jean-Michel Verger, Maggy Grayon, \\ Michel S. Zygmunt and Axel Cloeckaert
}

Laboratoire de Pathologie Infectieuse et Immunologie, Centre de Recherches de Tours, Institut National de la Recherche Agronomique, 37380 Nouzilly, France
Author for correspondence: Axel Cloeckaert. Tel: +332474278 72. Fax: +332474277 79 . e-mail: Axel.Cloeckaert@tours.inra.fr

The omp-31 gene, encoding a major outer-membrane protein in Brucella melitensis, was PCR-amplified from Brucella strains representing all species and known biovars by using primers selected according to the $B$. melitensis $16 \mathrm{M}$ omp-31 published sequence. Amplification of omp-31 was achieved from DNA of all Brucella species with the exception of Brucella abortus, the only Brucella species where expression of omp-31 was not detected by reactivity with an mAb specific for an epitope located in Omp-31. Southern blot hybridization of plasmid probes, bearing inserts (4.4-17 kb) containing B. melitensis 16M omp-31 and adjacent DNA of different sizes, with HindIIIdigested total DNA showed that a large fragment, comprising the entire omp31 gene and flanking DNA, was actually absent in B. abortus strains. The size of this DNA fragment has been determined to be about $10 \mathrm{~kb}$. Southern blot hybridization with the different plasmid probes identified species-specific markers for B. abortus and B. melitensis. At the biovar level, a specific marker for B. melitensis bv. 1 was also identified. Additionally, PCR-RFLP studies of omp-31 revealed specific markers for Brucella ovis, Brucella canis and Brucella suis bv. 2. Using a combination of omp-31 PCR-RFLP patterns and Southern blot hybridization profiles Brucella species were differentiated with the sole exception of Brucella neotomae which was not differentiated from B. suis bv. $1,3,4$ and 5. Results presented in this paper demonstrate the potential of omp-31 for differentiating the brucellae and show that B. abortus lacks a large DNA fragment of about $10 \mathrm{~kb}$ containing omp-31 and flanking DNA. In such a large deletion, other genes in addition to omp-31 are probably involved. Sequencing of this DNA fragment will help to identify the missing genes in $B$. abortus which could possibly be involved in the differences of pathogenicity and host preference seen in Brucella species.

Keywords: Brucella, omp-31, DNA polymorphism, outer-membrane protein

\section{INTRODUCTION}

Brucella strains are the causative agents of brucellosis, a widespread infectious disease affecting many animal species and man. Six species, classified on the basis of differences in pathogenicity and host preference, are

†Present address: Dpto Microbiologra y Genética, Edificio Departamental, Universidad de Salamanca, Avda. Campo Charro s/n, 37007 Salamanca, Spain.

Abbreviation: OMP, outer-membrane protein. recognized within the genus Brucella: $B$. melitensis, B. abortus, B. suis, B. ovis, B. canis and B. neotomae (Corbel \& Brinley-Morgan, 1984). Differentiation between these species and their different biovars is currently based on serotyping, phage typing, dyesensitivities, $\mathrm{CO}_{2}$ requirement, $\mathrm{H}_{2} \mathrm{~S}$ production and metabolic properties (Alton et al., 1988). However, reported instability for some of these phenotypic characteristics (Meyer, 1976) sometimes makes it difficult to identify particular isolates. Therefore, the identification of stable DNA-specific markers is considered a high 
Table 1. Brucella strains used in this study

\begin{tabular}{|c|c|c|c|c|}
\hline No. & Species and strain* & Biovar & Host/source & Geographic origin \\
\hline & B. abortus & & & \\
\hline 1 & 544 (ATCC 23448; BCCN R4)† & 1 & Cattle & England \\
\hline 2 & 86/8/59 (ATCC 23449; BCCN R5) & 2 & Cattle & England \\
\hline 3 & Tulya (ATCC 23450; BCCN R6) & 3 & Human & Uganda \\
\hline 4 & 292 (ATCC 23451; BCCN R7) & 4 & Cattle & England \\
\hline 5 & B3196 (ATCC 23452; BCCN R8) & 5 & Cattle & England \\
\hline 6 & 870 (ATCC 23453; BCCN R9) & 6 & Cattle & Africa \\
\hline 7 & C68 (ATCC 23455; BCCN R11) & 9 & Cattle & England \\
\hline 8 & $45 / 20$ (BCCN V2)‡ & $\mathbf{R}$ & Cattle & England \\
\hline \multirow[t]{2}{*}{9} & RB51 (BCCN V5) $\ddagger$ & $\mathbf{R}$ & Cattle & USA \\
\hline & B. melitensis & & & \\
\hline 10 & 16M (ATCC 23456; BCCN R1) † & 1 & Goat & USA \\
\hline 11 & $\mathrm{H} 38$ (BCCN V3) $\neq$ & 1 & Human & Mexico \\
\hline 12 & Rev.1 (BCCN V4a) $\ddagger$ & 1 & Goat & Mexico \\
\hline 13 & BCCN 90.61 & 1 & Sheep & South Africa \\
\hline 14 & BCCN 92.70 & 1 & Human & France \\
\hline 15 & BCCN 94.37 & 1 & Human & France \\
\hline 16 & BCCN 87.92 & 1 & Human & USA \\
\hline 17 & BCCN $92.106 \mathrm{c}$ & 1 & Unknown & Algeria \\
\hline 18 & BCCN 75.477 & 1 & Dog & Israel \\
\hline 19 & BCCN 88.42 & 1 & Sheep & Israel \\
\hline 20 & 63/9 (ATCC 23457; BCCN R2) & 2 & Goat & Turkey \\
\hline 21 & BCCN 95.33 & 2 & Sheep & Italy \\
\hline 22 & Ether (ATCC 23458; BCCN R3) & 3 & Goat & Italy \\
\hline 23 & BCCN 95.30 & 3 & Sheep & Italy \\
\hline 24 & BCCN 94.16 & 3 & Cattle & France \\
\hline 25 & $\mathrm{BCCN} 92.106 \mathrm{a}$ & 3 & Unknown & Algeria \\
\hline 26 & BCCN 92.42 & 3 & Human & Tunisia \\
\hline 27 & BCCN 92.118 & 3 & Human & Tunisia \\
\hline 28 & BCCN 92.80 & 3 & Sheep & Spain \\
\hline 29 & BCCN 92.83 & 3 & Sheep & Spain \\
\hline 30 & B115 (BCCN R19) & $\mathrm{R}$ & Goat & Malta \\
\hline 31 & BCCN 92.116 & $\mathbf{R}$ & Sheep & France \\
\hline \multirow[t]{2}{*}{32} & BCCN 94.62 & $\mathbf{R}$ & Human & France \\
\hline & B. suis & & & \\
\hline 33 & 1330 (ATCC 23444; BCCN R12) † & 1 & Swine & USA \\
\hline 34 & S2 (BCCN V6) $\ddagger$ & 1 & Swine & China \\
\hline 35 & Thomsen (ATCC 23445; BCCN R13) & 2 & Swine & Denmark \\
\hline 36 & BCCN 94.9 & 2 & Hare & France \\
\hline 37 & BCCN 94.10 & 2 & Hare & France \\
\hline 38 & BCCN 94.11 & 2 & Wild boar & France \\
\hline 39 & BCCN 93.60 & 2 & Swine & France \\
\hline 40 & BCCN 93.21 & 2 & Hare & France \\
\hline 41 & BCCN 93.72 & 2 & Swine & Spain \\
\hline 42 & BCCN 93.74 & 2 & Swine & Spain \\
\hline 43 & BCCN 93.77 & 2 & Swine & Spain \\
\hline 44 & BCCN 93.78 & 2 & Swine & Spain \\
\hline 45 & BCCN 96.122 & 2 & Wild boar & France \\
\hline 46 & BCCN 96.123 & 2 & Swine & France \\
\hline 47 & 686 (ATCC 23446; BCCN R14) & 3 & Swine & USA \\
\hline 48 & 40 (ATCC 23447; BCCN R15) & 4 & Reindeer & Former Soviet Union \\
\hline 49 & 513 (BCCN R21) & 5 & Wild rodent & Former Soviet Union \\
\hline
\end{tabular}


Table 1 (cont.)

\begin{tabular}{|lllll|}
\hline No. & \multicolumn{1}{c}{ Species and strain* } & Biovar & Host/source & Geographic origin \\
\hline & B. ovis & & & \\
50 & 63/290 (ATCC 25840; BCCN R17) & - & Sheep & Africa \\
51 & Reo 198 (BCCN R22) & - & Sheep & USA \\
52 & BCCN 76.247 & - & Sheep & France \\
53 & BCCN 76.250 & - & Sheep & France \\
54 & BCCN 91.70 & - & Sheep & Spain \\
55 & BCCN 91.208 & - & Sheep & Spain \\
56 & BCCN 91.212 & - & Sheep & Spain \\
57 & BCCN 91.217 & - & Sheep & Spain \\
58 & BCCN 91.266 & - & Sheep & Argentina \\
& B. canis & & & \\
59 & RM6/66 (ATCC 23365; BCCN R18)† & - & Dog & USA \\
60 & BCCN C1 & - & Dog & Madagascar \\
61 & BCCN C2 & - & Dog & USA \\
62 & BCCN C3 & - & Dog & USA \\
63 & BCCN C4 & - & Dog & USA \\
64 & BCCN 87.62 & - & Unknown & Mexico \\
65 & BCCN 87.66 & - & Dog & Canada \\
66 & BCCN 87.65 & - & Dog & Canada \\
67 & BCCN 96.103 & - & Dog & Rumania \\
68 & BCCN 96.104 & - & Dog & Rumania \\
69 & BCCN 96.105 & - & Dog & Rumania \\
70 & BCCN 96.106 & - & Dog & Rumania \\
71 & BCCN 96.107 & - & Dog & Rumania \\
72 & BCCN 96.121 & - & Dog & France \\
73 & B. neotomae & - & Desert rat & USA \\
\hline
\end{tabular}

*ATCC, American Type Culture Collection; BCCN, Brucella Culture Collection, Nouzilly, France.

$\nmid$ Reference strain.

‡ Vaccine strain.

priority for diagnostic, epidemiological and taxonomic purposes.

Since the brucellae share a high degree of DNA homology ( $>90 \%$ for all species) and Brucella has been proposed as a mono-specific genus (Verger et al., 1985, 1987), several techniques have been employed to find DNA polymorphisms which would enable the molecular typing of the Brucella species and their different biovars (Allardet-Servent et al., 1988; Bricker \& Halling, 1994, 1995; Cloeckaert et al., 1995, 1996b; Fekete et al., 1992; Ficht et al., 1990, 1996; Grimont et al., 1992; Halling \& Zehr, 1990; Mercier et al., 1996; Ouahrani et al., 1993). Among these, detection of RFLPs is considered a reproducible and easily performed method.

Major outer-membrane protein (OMP) genes of Brucella have recently attracted attention as they exhibit sufficient polymorphism to allow differentiation between Brucella species and some of their biovars (reviewed by Cloeckaert et al., 1996c). Studies of the RFLP profiles of two closely related genes: omp $2 a$ and omp $2 b$, encoding and potentially expressing the Brucella spp. major OMP of $36 \mathrm{kDa}$ (Ficht et al., 1988, 1989), showed that the type strains of the six Brucella species could be differentiated on this basis (Ficht et al., 1990). More recently using PCR-RFLP and a greater number of restriction enzymes, Brucella species-, biovar-, or strain-specific markers have been detected for the omp25 gene, encoding the Brucella $25 \mathrm{kDa}$ major OMP (de Wergifosse et al., 1995), and for the omp2a and omp2 $b$ genes. However, $B$. canis remained undistinguishable from $B$. suis bv. 3 and 4 (Cloeckaert et al., 1995).

The $31-34 \mathrm{kDa}$ OMP has been identified as a minor OMP in B. abortus strains but as a major OMP in the other Brucella species (Dubray, 1981). The B. melitensis $16 \mathrm{M}$ gene encoding this protein (omp-31) has recently been cloned and sequenced (Vizcaíno et al., 1996). In the present work, we studied polymorphism at the omp-31 locus, by either Southern blot hybridization or PCRRFLP, of 73 Brucella reference and field strains representing the six species and their different biovars searching for DNA markers that could improve differentiation among the brucellae. 

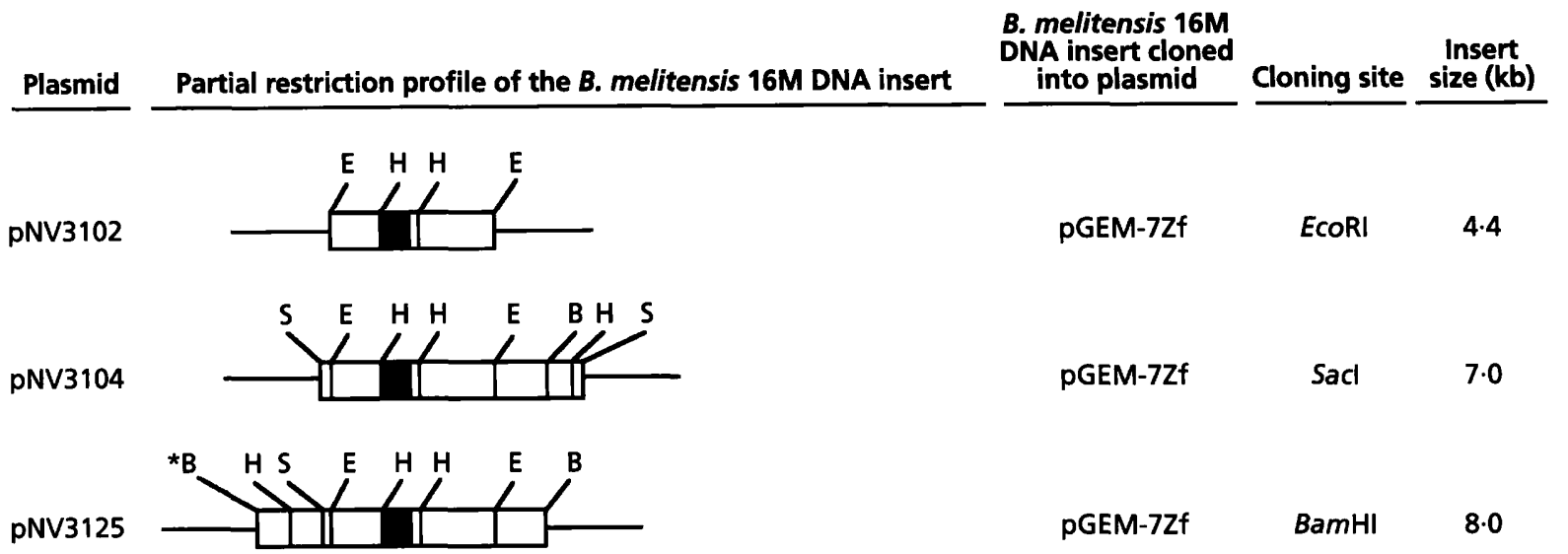

pGEM-7Zf Sacl

pGEM-7Zf BamHI

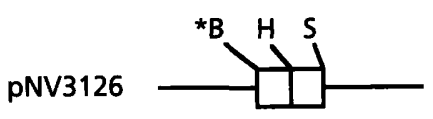

pGEM-7Zf BamHI-SaCl

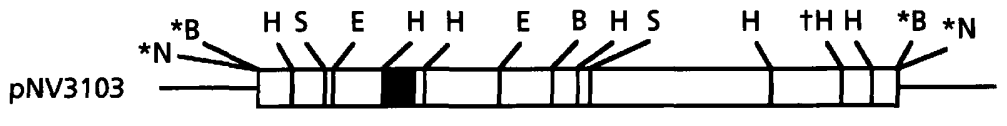

pGEM-5Zf

Notl

17

Fig. 1. Relevant characteristics of the plasmids used in this study. Plasmids were obtained by subcloning, into pGEM-5Zf or pGEM-7Zf, the DNA of a phage, bearing omp-31, from a $B$. melitensis $16 \mathrm{M}$ genomic library constructed in $\lambda \mathrm{GEM}-12$ (Vizcaino et al., 1996). The darkest region corresponds to location of omp-31 within the insert. Only the restriction map with some enzymes is shown and the EcoRI restriction map is not complete in pNV3103, pNV3104, pNV3125 and pNV3126. Sites marked with an asterisk probably correspond to the multiple cloning site of phage $\lambda \mathrm{GEM}-12$ and are absent in the Brucella DNA. The HindIII site marked by † could be symmetrically located between the two adjacent HindIII sites, closer to the HindIII site on its left. Restriction sites: B, BamHI; E, EcoRI; H, HindIII; N, Notl; S, Sacl.

\section{METHODS}

Bacterial strains and plasmids. The 73 Brucella strains used in this study are listed in Table 1 . All strains were maintained freeze-dried in the INRA Brucella Culture Collection, Nouzilly (BCCN), France. Cultures were grown on tryptic soy agar (Gibco-BRL) supplemented with $0 \cdot 1 \%(\mathrm{w} / \mathrm{v})$ yeast extract (Difco) (TSAYE). For fastidious strains (B. abortus bv. 2 and B. ovis), $5 \%$ sterile horse serum (Gibco-BRL) was added to TSAYE (TSAYES medium). The strains were checked for purity and species and biovar characterization by standard procedures (Alton et al., 1988). Escherichia coli JM109 cells bearing recombinant plasmids pNV3102, pNV3103, pNV3104, pNV3125 or pNV3126 were cultured overnight on LB medium containing $50 \mu \mathrm{g}$ ampicillin $\mathrm{ml}^{-1}$.

Plasmids pNV3102, pNV3103, pNV3104 and pNV3125 contain $B$. melitensis $16 \mathrm{M}$ DNA inserts bearing omp-31 and were obtained by subcloning, into pGEM-5Zf or pGEM-7Zf (Promega), the DNA insert of a phage from a $B$. melitensis $16 \mathrm{M}$ genomic library constructed in $\lambda$ GEM-12 XhoI half-site arms (Promega) as described previously (Vizcaíno et al., 1996). Plasmid pNV3126 was obtained by subcloning a BamHI-SacI fragment of pNV3125 into pGEM-7Zf. The relevant characteristics of the five plasmids are shown in Fig. 1.

Immunoblotting. SDS-PAGE was performed as described by Laemmli (1970) with bacterial suspensions diluted in Laemmli sample buffer and heated for $10 \mathrm{~min}$ at $100^{\circ} \mathrm{C}$. After electrophoresis, proteins were transferred at $0.8 \mathrm{~mA} \mathrm{~cm}^{-2}$ for $75 \mathrm{~min}$ to a nitrocellulose membrane. Detection of protein bands reacting with the anti-Omp-31 mAb A59/10F09/G10 (IgG2a) was accomplished as described previously (Vizcaíno et al., 1996).
DNA preparation. The strains were cultured for $24 \mathrm{~h}$ at $37^{\circ} \mathrm{C}$ on TSAYE or TSAYES slopes and harvested, in $3 \mathrm{ml}$ sterile distilled water, by centrifugation at $2000 \mathrm{~g}$ for $10 \mathrm{~min}$. The pellet was suspended in $567 \mu \mathrm{l} \mathrm{TE} /$ sodium buffer $(50 \mathrm{mM}$ Tris, $50 \mathrm{mM}$ EDTA, $100 \mathrm{mM} \mathrm{NaCl}, \mathrm{pH} 8 \cdot 0)$. Then, $30 \mu \mathrm{l} 10 \%$ $(\mathrm{w} / \mathrm{v}) \mathrm{SDS}$ solution and $3 \mu \mathrm{l} 2 \%(\mathrm{w} / \mathrm{v})$ proteinase $\mathrm{K}$ solution were added and the mixture was kept at $37^{\circ} \mathrm{C}$ for $1 \mathrm{~h}$. The lysed cell suspension was extracted twice with phenolchloroform and nucleic acids were precipitated by gently mixing the aqueous phase with 2 vols cold ethanol. The precipitate was dissolved in $100 \mu \mathrm{l}$ TE (10 mM Tris, $1 \mathrm{mM}$ EDTA, pH 8.0). The amount of DNA was measured by electrophoresis of an aliquot of each sample through $0.8 \%$ agarose gels and comparison with standard DNA solutions.

Southern blot hybridization. DNA from Brucella strains was digested with HindIII and fragments resolved by agarose gel electrophoresis and transferred onto Immobilon-S nylon membranes (Millipore) by vacuum transfer with the VacuGene System (Pharmacia LKB Biotechnology).

pNV3102, pNV3103, pNV3104, pNV3125, pNV3126 and PCR amplified $B$. melitensis $16 \mathrm{M}$ omp-31 were biotin-labelled with the NEBlot Phototope kit (New England Biolabs), following the instructions of the manufacturer, and used as probes for hybridization with the transferred HindIII-digested Brucella spp. DNA. Detection of HindIII Brucella spp. DNA fragments hybridizing with the biotinylated probes was performed with the Phototope-Star Detection kit for Nucleic Acids (New England Biolabs), according to the manufacturer's instructions, and exposure of the hybridized membranes to an X-ray film (Dupont).

A mixture of biotinylated HindIII digest of $\lambda$ DNA and HaeIII 
digest of $\phi \mathrm{X} 174$ DNA (Biolabs) was used as molecular size markers.

Primers and amplification conditions. Two 20 -mer primers (Isoprim) were selected according to the reported omp-31 nucleotide sequence (Vizcaíno et al., 1996) to amplify the entire omp-31 with its putative Shine-Dalgarno and transcription terminator sequences. These primers were 31 sd $\left(5^{\prime}\right.$ TGACAGACTTTTTCGCCGAA- $\left.{ }^{\prime}\right)$ and 31 ter ( $5^{\prime}$-CATTCAGGACAATTCCCGCC-3').

Amplification reaction mixtures were prepared in volumes of $100 \mu \mathrm{l}$ containing $10 \mathrm{mM}$ Tris $/ \mathrm{HCl}(\mathrm{pH} \mathrm{9.0)}, 50 \mathrm{mM} \mathrm{KCl}$, $1.5 \mathrm{mM} \mathrm{MgCl}, 0 \cdot 1 \%$ Triton X-100, $0.2 \mathrm{mg}_{2}$ gelatin $\mathrm{ml}^{-1}(1 \times$ PCR buffer; Appligene), $200 \mu \mathrm{M}$ each dNTP, $1 \mu \mathrm{M}$ each primer, $100 \mathrm{ng}$ genomic DNA, and 2.5 U Taq DNA polymerase (Appligene). The temperature cycling for the amplification was performed in a GeneAmp PCR System 9600 thermocycler (Perkin Elmer) as follows: cycle 1 was $94^{\circ} \mathrm{C}$ for $5 \mathrm{~min}$ (denaturation); the next 30 cycles were $58^{\circ} \mathrm{C}$ for $30 \mathrm{~s}$ (annealing), $70^{\circ} \mathrm{C}$ for $30 \mathrm{~s}$ (extension) and $94^{\circ} \mathrm{C}$ for $30 \mathrm{~s}$ (denaturation); the last cycle was $58^{\circ} \mathrm{C}$ for $30 \mathrm{~s}$ (annealing) and $70^{\circ} \mathrm{C}$ for $10 \mathrm{~min}$ (extension).

Restriction digestion. For PCR-RFLP, the following restriction enzymes were used: AvaII, KpnI and Sau3AI (Appligene), BanI and HaelI (Promega), HaeIII and PvuII (New England Biolabs), RsaI and SalI (Gibco-BRL) and StyI (Boehringer Mannheim).

Restriction enzymes were chosen according to the B. melitensis $16 \mathrm{M}$ omp-31 determined nucleotide sequence (Vizcaíno et al., 1996). The omp-31 restriction map for the selected enzymes is shown in Fig. 5. Five microlitres of each PCR product were cleaved with 1-5 U each restriction enzyme in a $20 \mu$ l volume. Buffer and temperature conditions recommended by the manufacturers were used. Restriction fragments from each reaction were separated in gels with $1.5 \%(\mathrm{w} / \mathrm{v})$ agarose (Appligene) and $0.5 \mu \mathrm{g} \mathrm{ml}^{-1}$ ethidium bromide (Sigma). The 100 bp DNA ladder (Gibco-BRL) was used as molecular size markers.

\section{RESULTS}

\section{Expression of omp-31 in Brucella spp.}

Toyerify expression of omp-31 in Brucella spp., Brucella strains representing all species and known biovars were submitted to SDS-PAGE followed by immunoblotting against the anti-Omp-31 mAb A59/10F09/G10.

All biovars of $B$. melitensis and $B$. suis, and $B$. ovis, $B$. canis, and $B$. neotomae reference strains reacted in immunoblotting with the anti-Omp-31 mAb (Fig. 2), showing a multiple banding pattern ranging from 28 to $34 \mathrm{kDa}$ according to molecular mass protein standards, which is characteristic for Omp-31 (Vizcaíno et al., 1996).

In contrast, no reactivity of the anti-Omp-31 mAb was detected with any of the B. abortus biovars (Fig. 2), suggesting that (1) the specific epitope recognized by the $\mathrm{mAb}$ is not present in $B$. abortus Omp-31, or (2) the omp-31 gene is not expressed or (3) it is absent in B. abortus strains.

\section{Southern blot hybridization}

Biotin-labelled pNV3102, pNV3103, pNV3104 and pNV3125, and PCR-amplified B. melitensis $16 \mathrm{M}$ omp-

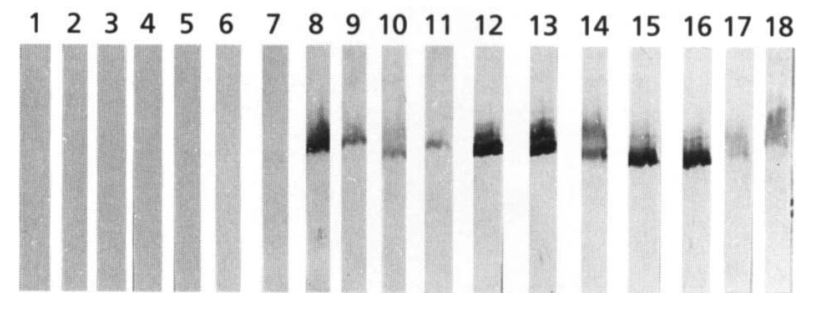

Fig. 2. Occurrence of Omp-31 in Brucella species and biovars. Immunoblotting with anti-Omp-31 mAb A59/10F09/G10 after SDS-PAGE of whole-cell lysates from $B$. abortus strains 544 (bv. 1) (lane 1), 86/8/59 (bv. 2) (lane 2), Tulya (bv. 3) (lane 3), 292 (bv. 4) (lane 4), B3196 (bv. 5) (lane 5), 870 (bv. 6) (lane 6), C68 (bv. 9) (lane 7); B. melitensis strains 16M (bv. 1) (lane 8), 63/9 (bv. 2) (lane 9), Ether (bv. 3) (lane 10); B. suis strains 1330 (bv. 1) (lane 11), Thomsen (bv. 2) (lane 12), 686 (bv. 3) (lane 13), 40 (bv. 4) (lane 14), 513 (bv. 5) (lane 15); B. ovis strain 63/290 (lane 16); B. canis strain RM6/66 (lane 17); B. neotomae strain 5K33 (lane 18).

31 were used as probes to detect hybridization with HindIII-digested DNA from Brucella strains representing the six species and their biovars.

The PCR-amplified omp-31 probe hybridized with one $1.6 \mathrm{~kb}$ HindIII fragment in genomic DNA from $B$. ovis, $B$. canis, B. neotomae and all biovars of $B$. suis (see arrowed band in Fig. 3a, lanes 6-9) and with one $0.9 \mathrm{~kb}$ HindIII fragment in DNA from the three biovars of B. melitensis (see arrowed band in Fig. 3a, lanes 3-5). No hybridization was detected with $B$. abortus DNA showing that omp-31 is absent in B. abortus strains. According to these results, the $o m p-31$ probe differentiated $B$. melitensis from the other Brucella species.

The pNV3102 probe, which contains a $4.4 \mathrm{~kb} B$. melitensis 16M DNA insert bearing omp-31 (Fig. 1), developed three bands $(1 \cdot 6,2 \cdot 4$ and $4 \mathrm{~kb})$ with DNA from $B$. ovis, B. canis, B. neotomae and all biovars of $B$. suis (Fig. 3a, lanes 6-9). With this probe HindIII fragments of $0.9,2.4$ and $4.3 \mathrm{~kb}$ were detected with B. melitensis $16 \mathrm{M}$ (bv. 1) DNA (Fig. 3a, lane 3) and fragments of $0.6,0.9,2.4$ and $4 \mathrm{~kb}$ with $B$. melitensis 63/9 (bv. 2) DNA (Fig. 3a, lane 4) and B. melitensis Ether (bv. 3) DNA (Fig. 3a, lane 5). The pNV3102 probe did not hybridize with DNA of the $B$. abortus biovars (Fig. 3a, lane 2). Thus, the pNV3102 probe distinguished $B$. melitensis bv. 1 from bv. 2 and 3 of the same species and also differentiated the three $B$. melitensis biovars from the other Brucella species.

The pNV3104 and pNV3125 (Fig. 1) probes containing inserts of respectively 7.0 and $8.0 \mathrm{~kb}$ did not hybridize with $B$. abortus DNA and the same banding pattern as that detected with pNV3102, with an additional $5 \mathrm{~kb}$ band (see arrowed band in Fig. 3b), was observed with the other Brucella species (data not shown).

However, when pNV3103 containing an insert of $17 \mathrm{~kb}$ (Fig. 1) was used as a probe, hybridization with three HindIII fragments $(0 \cdot 7,2$ and $6 \mathrm{~kb})$ was detected in DNA from all biovars of $B$. abortus (Fig. 3b, lane 2) showing that DNA sequence from at least one side of the 
(a)

$\begin{array}{lllllllll}1 & 2 & 3 & 4 & 5 & 6 & 7 & 8 & 9\end{array}$

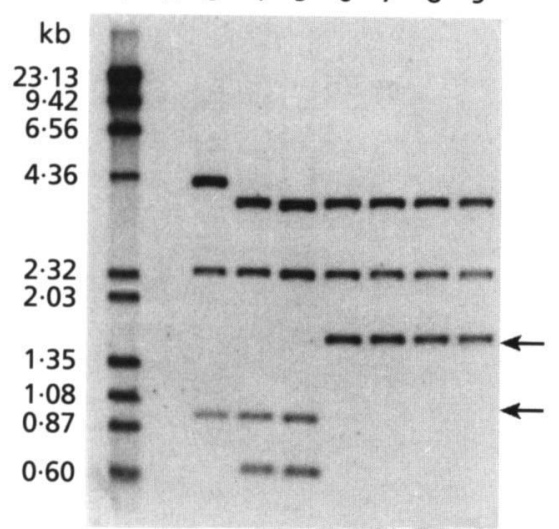

(b)

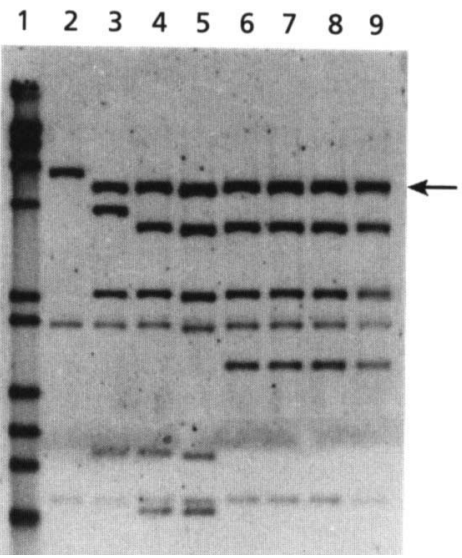

Fig. 3. Southern blot hybridization with biotinylated pNV3102 (a) and pNV3103 (b) probes. Lane 1, molecular size markers; lanes 2-9, HindIII digest of DNA from B. abortus 544 (bv. 1) (lane 2), B. melitensis $16 \mathrm{M}$ (bv. 1) (lane 3), B. melitensis 63/9 (bv. 2) (lane 4), B. melitensis Ether (bv. 3) (lane 5), B. suis 1330 (bv. 1) (lane 6), B. ovis 63/290 (lane 7), B. canis RM6/66 (lane 8) and B. neotomae 5K33 (lane 9). All B. abortus and $B$. suis biovars gave the same profile as shown in lanes 2 and 6, respectively. Arrows show the band observed with the biotinylated PCR-amplified omp-31 probe (a) and the $5 \mathrm{~kb}$ additional band, as compared with the biotinylated pNV3102 probe profile, of the profile observed with biotinylated pNV3104 and pNV3125 probes (b).
$B$. abortus deletion is present in the $B$. melitensis $16 \mathrm{M}$ DNA insert of pNV3103. The 0.7 and $2 \mathrm{~kb}$ HindIII fragments were also detected in the other Brucella species (Fig. 3b, lanes 3-9), not revealing additional polymorphism to that detected with the pNV3102 probe (Fig. 3a, lanes 3-9). The use of the pNV3103 probe thus differentiated B. abortus and B. melitensis from each other and from the other Brucella species (Fig. 3b). Moreover, $B$. melitensis bv. 1 was distinguishable from the two other biovars of the same species (Fig. 3b, lanes 3-5).

To determine whether the DNA delimiting both sides of the $B$. abortus deletion was contained in the B. melitensis $16 \mathrm{M}$ DNA insert of pNV3103, the biotinylated insert of plasmid pNV3126 (Fig. 1) was used as a probe to hybridize with HindIII-digested B. abortus 544 DNA. Only one band, located between the 9.4 and $23.1 \mathrm{~kb}$ DNA markers, was weakly detected. This band did not appear with probes pNV3125 or pNV3103, both containing the pNV3126 insert (Fig. 1), which could be explained by the greater molecular size of these probes. As three additional bands were detected after hybridization of the pNV3103 probe with $B$. abortus DNA, these results suggest that the entire DNA fragment deleted in B. abortus is contained in the B. melitensis $16 \mathrm{M}$ insert of pNV3103. Nucleotide sequence at both ends of the pNV3103 insert was determined, as previously described (Vizcaíno et al., 1996), by using the pGEM-5Zf M13 reverse and forward primers (data not shown) and PCR amplification from B. abortus DNA was performed with primers selected according to the identified sequences. A DNA band of about $7 \mathrm{~kb}$ was detected on agarose gels (data not shown) thus delimiting the missing DNA in $B$. abortus to a fragment of about $10 \mathrm{~kb}$ of the pNV3103 B. melitensis 16M DNA insert.

\section{RFLP of the omp-31 gene}

Ten restriction enzymes, chosen according to the restriction map deduced from the B. melitensis $16 \mathrm{M}$ omp31 nucleotide sequence (Vizcaíno et al., 1996), were used

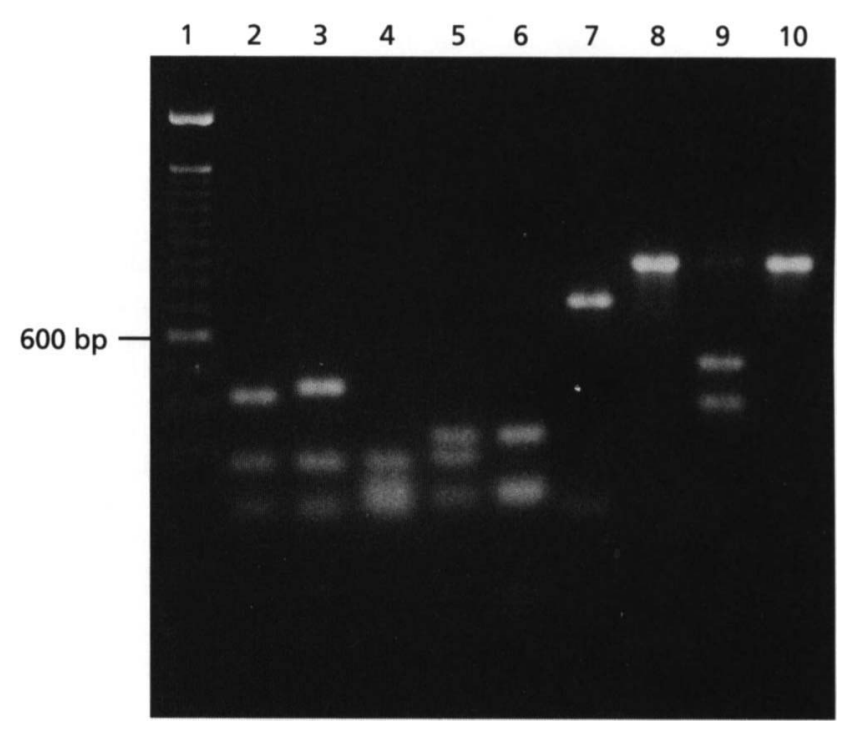

Fig. 4. Restriction patterns of the PCR-amplified omp-31 gene. The patterns P1-P3 of Table 2 are shown for each enzyme. Lanes: 1, molecular size markers; $2-4$, patterns $P 1, P 2$ and P3 with Avall; 5 and 6, patterns $P 1$ and $P 2$ with Haell ; 7 and 8, patterns P1 and P2 with Sall; 9 and 10, patterns P1 and P2 with Sau3Al.

to study the RFLP in the PCR-amplified omp-31 genes from the different brucellae. Brucella reference and field strains representing all species and their biovars were included in this study, with the exception of $B$. abortus strains where PCR-amplification of omp-31 was unsuccessful. For each restriction enzyme, pattern P1 was assigned to strains showing the same restriction pattern to that deduced from the B. melitensis $16 \mathrm{M}$ omp-31 nucleotide sequence (Vizcaíno et al., 1996).

Six restriction enzymes (BanI, HaeII, KpnI, PvuII, RsaI and StyI) did not reveal any omp-31 polymorphism among the brucellae, giving the same restriction pattern with all the strains tested (data not shown).

AvalI gave three different restriction patterns (Fig. 4, lanes 2-4; Table 2). Restriction pattern P1 (Fig. 4, lane 
omp-31 polymorphism in Brucella spp.

Table 2. Restriction patterns of the PCR-amplified omp-31 gene of the different Brucella strains

\begin{tabular}{|c|c|c|c|c|c|c|}
\hline \multirow[t]{2}{*}{ Species } & \multirow[t]{2}{*}{ Biovar } & \multirow[t]{2}{*}{ Pattern* } & \multicolumn{4}{|c|}{ Pattern with restriction enzymes $\nmid$} \\
\hline & & & AvalI & HaeIII & SalI & Sau3AI \\
\hline B. abortus (strains 1-9) $\ddagger$ & $1-9, \mathrm{R}$ & $\begin{array}{c}\text { Not } \\
\text { amplified }\end{array}$ & & & & \\
\hline B. melitensis (strains $10-32) \ddagger$ & $1-3, \mathrm{R}$ & A & P1 & P1 & P1 & P1 \\
\hline B. suis (strains $33,34,47-49) \ddagger$ & $1,3-5$ & A & P1 & P1 & P1 & P1 \\
\hline B. suis (strains 36,40$) \ddagger$ & 2 & B & $\mathrm{P} 2$ & P1 & P1 & P1 \\
\hline B. suis (strains $35,37-39,41-46$ ) & 2 & $\mathrm{C}$ & $\mathrm{P} 2$ & $\mathrm{P} 2$ & P1 & $\mathrm{P} 1$ \\
\hline B. ovis (strains $50-58) \ddagger$ & & $\mathrm{D}$ & P1 & P1 & P1 & $\mathrm{P} 2$ \\
\hline B. canis (strains $59-63,65,67-72) \ddagger$ & & $\mathrm{E}$ & P3 & P1 & P1 & P1 \\
\hline B. canis (strains 64,66$) \neq$ & & $\mathrm{F}$ & P3 & P1 & P2 & P1 \\
\hline B. neotomae (strain 73 ) & & $\mathrm{A}$ & P1 & P1 & P1 & P1 \\
\hline
\end{tabular}

*Overall pattern of omp-31, cut with the different restriction enzymes, for each Brucella strain.

† BanI, HaeII, KpnI, PvuII, RsaI and StyI were also used. For each of these enzymes pattern P1 was obtained with all Brucella strains tested. $\ddagger$ Strain numbers as referred to in first column of Table 1 .

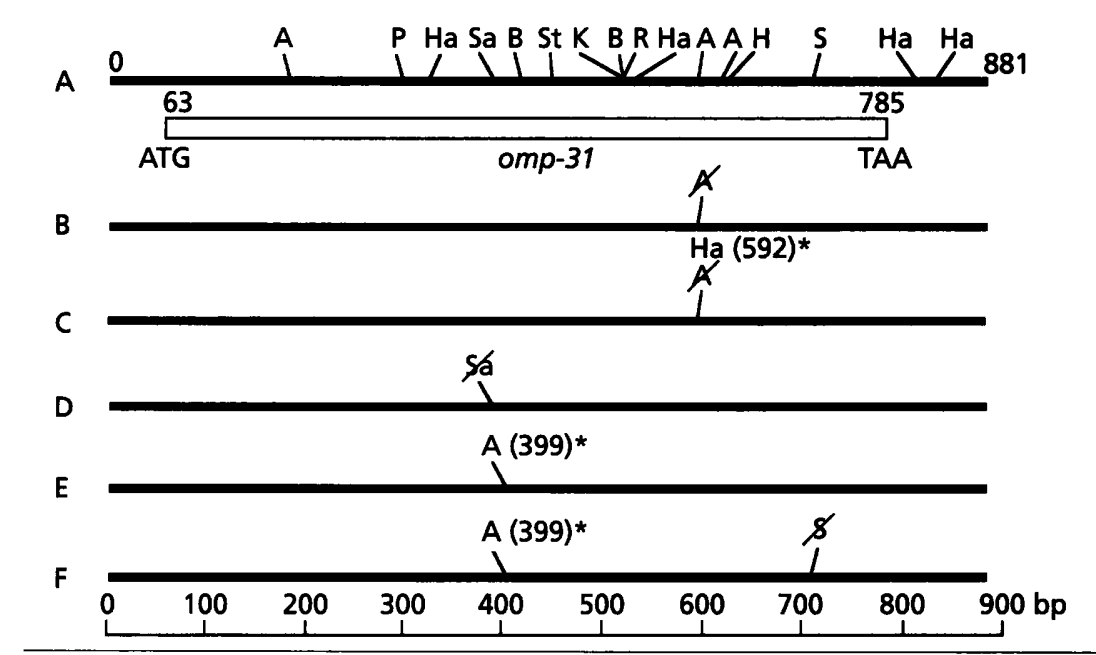

Fig. 5. Restriction maps of the PCRamplified omp-31 gene of Brucella species and biovars. Restriction map of pattern $A$ was deduced from the nucleotide sequence of the $B$. melitensis $16 \mathrm{M}$ omp-31 gene (Vizcaino et al., 1996). Patterns B-F of Table 2 were established by comparison with pattern A and only differences with pattern $A$ are shown. Missing restriction sites in the omp-31 gene of strains showing patterns $B-F$ are barred. Additional restriction sites and their most probable location according to restriction patterns and single nucleotide substitutions in the omp-31 gene sequence of $B$. melitensis $16 \mathrm{M}$ are indicated by the enzyme name and the most probable location by the position number and an asterisk. Restriction sites: A, Avall; B, Banl; H, Haell; Ha, Haelli; K, Kpnl; P, Pvull; R, Rsal; S, Sall; Sa, Sau3Al; St, Styl.

2) was observed with all strains of B. melitensis, B. ovis and $B$. neotomae, and with all $B$. suis strains belonging to bv. 1, 3, 4 and 5 (Table 2). Restriction pattern $\mathrm{P} 2$ was characteristic to B. suis bv. 2 strains (Fig. 4, lane 9), and pattern P3 to B. canis strains (Fig. 4, lane 10). Thus, omp-31 restriction with AvaII allowed the distinction of $B$. suis bv. 2 and B. canis from each other and from the other brucellae.

HaelII allowed the differentiation of $B$. suis bv. 2 strains (pattern P2) (Fig. 4, lane 6; Table 2) from the other Brucella strains (pattern P1) (Fig. 4, lane 5; Table 2), with the exception of strains numbered 36 and 40 which showed pattern P1 as the other Brucella strains (Table 2). SalI showed a different pattern with only two strains (strains numbered 64 and 66) of B. canis (Fig. 4, lanes 7 and 8; Table 2). Finally, Sau3AI gave a species-specific marker to $B$. ovis strains showing pattern P2 (Fig. 4, lane
10) distinguishable from pattern P1 (Fig. 4, lane 9) of the other Brucella strains (Table 2).

According to the RFLP detected in the omp-31 gene with the ten restriction enzymes used in this study, Brucella strains could be classified into seven groups (Table 2) including $B$. abortus strains where omp-31 was not amplified. The six omp-31 restriction maps obtained with the ten enzymes used are represented in Fig. 5. and are classified into overall patterns A-F (see also Table 2 ). Pattern A was specific for B. melitensis, B. neotomae and $B$. suis bv. 1, 3, 4 and 5. Pattern B, characterized by the absence of the AvaII site located at position 592, was detected with two strains of $B$. suis bv. 2 (strains numbered 36 and 40 ) while most of $B$. suis bv. 2 strains showed pattern $C$ which corresponds to pattern $B$ with an additional HaeIII site probably located at the same 592 position. All B. ovis strains tested showed pattern D, 
characterized by the absence of the Sau3AI (385) site. B. canis strains showed pattern $\mathrm{E}$ (pattern $\mathrm{A}$ with an additional Avall site probably located at position 399) or pattern $\mathrm{F}$ (two $B$. canis strains) which corresponds to pattern E lacking the SalI (708) site.

\section{DISCUSSION}

In the present study, expression of omp-31 in the brucellae has been examined with an $\mathrm{mAb}$ specific for an epitope located in Omp-31. Reactivity was detected with all Brucella species and biovars with the exception of B. abortus strains. The reasons for this may be that (1) the epitope recognized by the $\mathrm{mAb}$ is not present in B. abortus Omp-31 or that (2) omp-31 is not expressed or that (3) omp-31 is absent in this species. PCR amplification of omp-31 from B. abortus DNA was unsuccessful with the selected primers and, furthermore, no hybridization was detected between PCR-amplified B. melitensis $16 \mathrm{M}$ omp-31 probe and HindIII-digested $B$. abortus total DNA. These results demonstrate that the entire omp-31 gene is absent in B. abortus strains and therefore that Omp-31 cannot be present among the $B$. abortus OMPs. Deletions in genes blocking or not the expression of the encoded protein have been reported in some Brucella species or strains (Cloeckaert et al., 1996a, c, d; Sangari et al., 1994), and in some cases lack of expression of an existing gene has been demonstrated (Ficht et al., 1989; Halling \& Zehr, 1990). However, this is the first report describing the deletion of an entire gene in one of the Brucella species. Moreover, hybridization of HindIII-digested Brucella spp. DNA with plasmid probes containing $B$. melitensis $16 \mathrm{M}$ DNA inserts of several sizes and bearing omp-31, revealed that a large DNA fragment, with a size of about $10 \mathrm{~kb}$, is deleted in B. abortus strains. In such a large fragment other genes, in addition to omp-31, are probably included. In spite of the high degree of DNA homology detected in the Brucella genus (Hoyer \& McCullough, 1968a, b; Verger et al., 1985), here we report significant differences at the genetic level in one Brucella species which could be involved in some of the phenotypic and/or pathogenic characteristics that differentiate the Brucella species.

Results presented in this paper do not allow us to explain the mechanism responsible for the deletion of this $10 \mathrm{~kb}$ DNA fragment in B. abortus. However, a $B$. melitensis $16 \mathrm{M}$ DNA fragment of $1.8 \mathrm{~kb}$ (cloned into plasmid pNV3126), which only contains one HindIII restriction site and bears a portion of DNA flanking one side of the B. abortus deletion, hybridized with more than two fragments of HindIII-digested DNA of the other Brucella species (data not shown). Indeed, this hybridization pattern was observed with all Brucella spp. biovars with the exception of the seven $B$. abortus biovars which developed only one band. This result suggests that the $1.8 \mathrm{~kb}$ insert of pNV3126 contains a DNA element which is repeated along the chromosome in all brucellae except B. abortus. Moreover, according to the HindIII restriction profile and the Southern blot pattern of pNV3103, a plasmid bearing a $17 \mathrm{~kb} \mathrm{~B}$. melitensis $16 \mathrm{M}$ insert covering the $10 \mathrm{~kb}$ region deleted in B. abortus and flanking DNA, it seems probable that the repeated element is present in more than one copy in the pNV3103 DNA insert. As repeated DNA elements, such as insertion sequences, have been suggested to be involved in the mechanism of deletion process of large chromosomal DNA segments (Fetherston \& Perry, 1994), location of this repeated element flanking both sides of the $10 \mathrm{~kb}$ DNA fragment deleted in B. abortus would provide a possible explanation for the origin of this deletion. Studies to determine the nucleotide sequence of this fragment and adjacent DNA are currently being performed in our laboratory and these will help both to identify the genes located in the $10 \mathrm{~kb}$ fragment and to determine the nature and possible role of the repeated element in the deletion process.

Several techniques have been employed in an attempt to find suitable DNA markers for the molecular typing of the Brucella genus. Some of these methods do not involve known Brucella gene sequences (AllardetServent et al., 1988; Fekete et al., 1992; Grimont et al., 1992; Mercier et al., 1996) and others take advantage of identified genes or insertion sequences (Bricker \& Halling, 1994, 1995; Cloeckaert et al., 1995, 1996b, c; Ficht et al., 1990, 1996; Halling \& Zehr, 1990; Ouahrani et al., 1993). Among them, PCR-RFLP with Brucella spp. OMP genes has been shown to be an interesting method for the differentiation of the brucellae (Cloeckaert et al., 1995). PCR-RFLP studies with omp2a, omp2b and omp25 from all Brucella species and biovars have allowed the differentiation of all Brucella species and some of their biovars, with the sole exception of $B$. canis which remained indistinguishable from $B$. suis bv. 3 and 4 (Cloeckaert et al., 1995). B. canis and B. suis bv. 3 and 4 have been reported to be closely related on the basis of phenotypic characteristics (Meyer, 1990) which can explain the difficulties found in their differentiation at the molecular level. In the present work, PCR-RFLP analysis with Brucella spp. omp-31 has allowed the identification of a $B$. canis-specific marker that makes this species distinguishable from the other Brucella species and their biovars, including $B$. suis bv. 3 and 4 . Moreover, specific markers for $B$. ovis and B. suis bv. 2 have also been found.

In addition to DNA markers detected by PCR-RFLP, other markers have been found by Southern blot hybridization with plasmids probes containing omp-31 and adjacent DNA, identifying omp-31 as an interesting gene for the differentiation of Brucella strains. By combining PCR-RFLP patterns and Southern blot hybridization results, differentiation of all Brucella species can be acomplished with the exception of $B$. neotomae which remains indistinguishable from $B$. suis bv. 1, 3, 4 and 5. Moreover, biovar-specific markers have been found for B. melitensis bv. 1 and B. suis bv. 2 .

In summary, work presented in this paper, regarding polymorphism at the omp-31 locus, has allowed the identification of useful DNA markers for the differentiation among the brucellae and has provided the first evidence for the absence of at least one gene in one 
Brucella species. Further work is necessary to identify the other missing genes in $B$. abortus and to determine their possible roles in the development of the infectious process. This may lead to a better understanding of differences in pathogenicity and host preference in Brucella species.

\section{REFERENCES}

Allardet-Servent, A., Bourg, G., Ramuz, M., Pages, M., Bellis, M. \& Roizes, G. (1988). DNA polymorphism in strains of the genus Brucella. J Bacteriol 170, 4603-4607.

Alton, G. G., Jones, L. M., Angus, R. D. \& Verger, J. M. (1988). Techniques for the Brucellosis Laboratory. Paris: Institut $\mathrm{Na}$ tional de la Recherche Agronomique.

Bricker, B. J. \& Halling, S. M. (1994). Differentiation of Brucella abortus bv. 1, 2, and 4, Brucella melitensis, Brucella ovis, and Brucella suis bv. 1 by PCR. J Clin Microbiol 32, 2660-2666.

Bricker, B. J. \& Halling, S. M. (1995). Enhancement of the Brucella AMOS PCR assay for differentiation of Brucella abortus vaccine strains S19 and RB51. J Clin Microbiol 33, 1640-1642.

Cloeckaert, A., Verger, J.-M., Grayon, M. \& Grépinet, O. (1995). Restriction site polymorphism of the genes encoding the major $25 \mathrm{kDa}$ and $36 \mathrm{kDa}$ outer-membrane proteins of Brucella. Microbiology 141, 2111-2121.

Cloeckaert, A., Debbarh, H. S. A., Vizcaíno, N., Saman, E., Dubray, G. \& Zygmunt, M. S. (1996a). Cloning, nucleotide sequence, and expression of the Brucella melitensis bp26 gene coding for a protein immunogenic in infected sheep. FEMS Microbiol Lett 140, 139-144.

Cloeckaert, A., Verger, J. M., Grayon, M. \& Grépinet, O. (1996b). Polymorphism at the dnaK locus of Brucella species and identification of a Brucella melitensis species-specific marker. J Med Microbiol 45, 200-205.

Cloeckaert, A., Verger, J. M., Grayon, M. \& Vizcaíno, N. (1996c). Molecular and immunological characterization of the major outer membrane proteins of Brucella. FEMS Microbiol Lett 145, 1-8.

Cloeckaert, A., Verger, J. M., Grayon, M., Zygmunt, M. S. \& Grépinet, O. (1996d). Nucleotide sequence and expression of the gene encoding the major 25-kilodalton outer membrane protein of Brucella ovis: evidence for antigenic shift, compared with the other Brucella species, due to a deletion in the gene. Infect Immun 64, 2047-2055.

Corbel, M. J. \& Brinley-Morgan, W. J. (1984). Genus Brucella Meyer and Shaw 1920, 173AL. In Bergey's Manual of Systematic Bacteriology, vol. 1, pp. 377-388. Edited by N. R. Krieg \& J. G. Holt. Baltimore: Williams \& Wilkins.

Dubray, G. (1981). Etude ultrastructurale et biochimique des enveloppes des bactéries du genre Brucella. PhD thesis. Université de Paris-Sud, Paris.

Fekete, A., Bantle, J. A., Halling, S. M. \& Stich, R. W. (1992). Amplification fragment length polymorphism in Brucella strains by use of polymerase chain reaction with arbitrary primers. J Bacteriol 174, 7778-7783.

Fetherston, J. D. \& Perry, R. D. (1994). The pigmentation locus of Yersinia pestis KIM6 + is flanked by an insertion sequence and includes the structural genes for pesticin sensitivity and HMWP2. Mol Microbiol 13, 697-708.

Ficht, T. A., Bearden, S. W., Sowa, B. A. \& Adams, L. G. (1988). A 36-kilodalton Brucella abortus cell-envelope protein is encoded by repeated sequences closely linked in the genomic DNA. Infect Immun 56, 2036-2046.

Ficht, T. A., Bearden, S. W., Sowa, B. A. \& Adams, L. G. (1989). DNA sequence and expression of the 36-kilodalton outer membrane protein gene of Brucella abortus. Infect Immun 57, 3281-3291.

Ficht, T. A., Bearden, S. W., Sowa, B. A. \& Marquis, H. (1990). Genetic variation at the omp2 porin locus of the brucellae: species-specific markers. Mol Microbiol 4, 1135-1142.

Ficht, T. A., Husseinen, H. S., Derr, J. \& Bearden, S. W. (1996). Species-specific sequences at the omp2 locus of Brucella type strains. Int J Syst Bacteriol 46, 329-331.

Grimont, F., Verger, J. M., Cornelis, P., Limet, J., Lefèvre, M., Grayon, M., Régnault, B., Van Broeck, J. \& Grimont, P. A. D. (1992). Molecular typing of Brucella with cloned DNA probes. Res Microbiol 143, 55-65.

Halling, S. M. \& Zehr, E. S. (1990). Polymorphism in Brucella spp. due to highly repeated DNA. J Bacteriol 172, 6637-6640.

Hoyer, B. H. \& McCullough, N. B. (1968a). Polynucleotide homologies of Brucella deoxyribonucleic acids. J Bacteriol 95, 444-448.

Hoyer, B. H. \& McCullough, N. B. (1968b). Homologies of deoxyribonucleic acids from Brucella ovis, canine abortion organisms, and other Brucella. J Bacteriol 96, 1783-1790.

Laemmli, U. K. (1970). Cleavage of structural proteins during the assembly of the head of bacteriophage T4. Nature 227, 680-685.

Mercier, E., Jumas-Bilak, E., Allardet-Servent, A., O'Callaghan, D. \& Ramuz, M. (1996). Polymorphism in Brucella strains detected by studying distribution of two short repetitive DNA elements. J Clin Microbiol 34, 1299-1302.

Meyer, M. E. (1976). Evolution and taxonomy in the genus Brucella: concepts on the origins of the contemporary species. Am J Vet Res 37, 199-202.

Meyer, M. E. (1990). Current concepts in the taxonomy of the genus Brucella. In Animal Brucellosis, pp. 2-13. Edited by K. Nielsen \& J. R. Duncan. Boca Raton, FL: CRC Press.

Ouahrani, S., Michaux, S., Widada, J. S., Bourg, G., Tournebize, R., Ramuz, M. \& Liautard, J. P. (1993). Identification and sequence analysis of IS6501, an insertion sequence in Brucella spp.: relationship between genomic structure and the number of IS6501 copies. J Gen Microbiol 139, 3265-3273.

Sangari, F. J., Garcla-Lobo, J. M. \& Agulero, J. (1994). The Brucella abortus vaccine strain B19 carries a deletion in the erythritol catabolic genes. FEMS Microbiol Lett 121, 337-342.

Verger, J. M., Grimont, F., Grimont, P. A. D. \& Grayon, M. (1985). Brucella, a monospecific genus as shown by deoxyribonucleic acid hybridization. Int J Syst Bacteriol 35, 292-295.

Verger, J. M., Grimont, F., Grimont, P. A. D. \& Grayon, M. (1987). Taxonomy of the genus Brucella. Ann Inst Pasteur Microbiol 138, 235-238.

Vizcaíno, N., Cloeckaert, A., Zygmunt, M. S. \& Dubray, G. (1996). Cloning, nucleotide sequence, and expression of the Brucella melitensis omp31 gene coding for an immunogenic major outer membrane protein. Infect Immun 64, 3744-3751.

de Wergifosse, P., Lintermans, P., Limet, J. N. \& Cloeckaert, A. (1995). Cloning and nucleotide sequence of the gene coding for the major 25 -kilodalton outer membrane protein of Brucella abortus. J Bacteriol 177, 1911-1914.

Received 7 March 1997; revised 12 May 1997; accepted 28 May 1997. 